Article

\title{
Achieving Water and Food Security in 2050: Outlook, Policies, and Investments
}

\section{Dennis Wichelns}

P.O. Box 2629, Bloomington, IN 47402, USA; E-Mail: dwichelns@csufresno.edu

Academic Editor: Stephen J. Herbert

Received: 15 March 2015 / Accepted: 11 April 2015 / Published: 22 April 2015

\begin{abstract}
Food production in 2050 will be sufficient, globally, but many of the poor will remain food insecure. The primary cause of food insecurity will continue to be poverty, rather than inadequate food production. Thus, policies and investments that increase the incomes of the poor will remain the best ways to extend food security to all. Investments that promote growth in sustainable agriculture and provide non-farm employment opportunities in rural areas of lower income countries will be most helpful. There will be sufficient water, globally, to achieve food production goals and sustain rural and urban livelihoods, if we allocate and manage the resource wisely. Yet, water shortages will constrain agricultural production and limit incomes and livelihood opportunities in many areas. Policies and investments are needed to extend and ensure access to water for household use and agricultural production. Challenges requiring the attention of policy makers and investors include increasing urbanization and increasing demands for land and water resources. Policy makers must ensure that farmers retain access to the water they need for producing food and sustaining livelihoods, and they must create greater opportunities for women in agriculture. They must also motivate investments in new technologies that will enhance crop and livestock production, particularly for smallholders, and encourage the private sector to invest in activities that create employment opportunities in rural areas.
\end{abstract}

Keywords: agriculture; livelihoods; poverty; smallholders; sustainability; women

\section{Introduction}

The Millennium Development Goals (MDGs), and their targets pertaining to 2015, motivated notable advances in poverty reduction, and in the health and welfare of women and children in many lower 
income countries [1-3]. The international community is now engaged in the process of defining and agreeing upon a new set of global objectives pertaining more broadly to the notion of achieving sustainable economic development [4]. Two of the 17 proposed Sustainable Development Goals (SDGs) align closely with issues regarding water and food security [5]. In particular, SDG 2 calls for ending hunger, achieving food security, and improving nutrition, while promoting sustainable agriculture. SDG 6 calls for ensuring the availability and sustainable management of water and sanitation for all [6].

The objectives listed within SDG 2 describe both the demand and supply aspects of food security. In addition to calling for universal access to safe, nutritious, and sufficient food, the objectives call for doubling the agricultural productivity and incomes of small-scale food producers, with a particular focus on women, indigenous peoples, family farmers, pastoralists, and fishers. They note also the importance of ensuring secure and equal access to land, other productive resources and inputs, knowledge, financial services, markets and opportunities for value addition, and non-farm employment [6]. It is essential that smallholders and their households have access to the resources and inputs needed to engage in livelihoods that will enable them to purchase food, particularly at times of short supplies and high prices.

Also embedded within SDG 2 is the call for ensuring sustainable food production systems and implementing resilient agricultural practices that increase productivity and production, while maintaining ecosystems, and mitigating the potential impacts of climate change [6]. To this end, it is essential that the international research community continue to generate global public goods, such as state-of-the-art research and outreach regarding climate-resilient agriculture, new varieties of cultivated plants, and improvements in livestock health and performance.

Several of the objectives within SDG 6 pertain to water supply, sanitation, and wastewater recovery, and several reflect issues involving agriculture more directly. For example, some of the objectives describe the need to increase water use efficiency in all sectors, achieve sustainable withdrawals of freshwater resources, implement integrated water resources management, protect the quality of lakes, rivers, wetlands, and aquifers, and substantially reduce the number of people impacted by water scarcity [6]. Although not stated explicitly, the need to ensure access to water for use in food production and in support of other livelihood activities is implied within these objectives, as noted by the call for achieving sustainable freshwater withdrawals, protecting water sources, and alleviating the impacts of water scarcity.

My goals in this paper are to review the outlook for water and food security to 2050, and describe some of the policies and investments that will be helpful in achieving the objectives put forth regarding water and food in the Sustainable Development Goals. I focus largely on agriculture, given the sector's notable role in providing employment and livelihoods in rural areas of lower income countries, while recognizing the potential implications of increasing urbanization. I describe also the importance of considering gender, climate change, and the environment when selecting investments and designing policies to promote the wise and sustainable use of land and water resources.

\section{The Outlook to 2050}

\subsection{Food Production}

It is likely there will be sufficient food to support the global population in 2050, even though the annual rates of increase in the yields of several important food crops have declined in recent years [7,8]. 
Successful efforts to supply sufficient food will include closing yield gaps in lower income countries, in part by increasing the use of better seeds and fertilizer, improving resource management, and enhancing the technology of crop production through advances in genomics and phenomics [9-13]. In addition, public officials must choose policies and investments that encourage increases in agricultural productivity on large and small farms, and in irrigated and rainfed settings [14-16]. Yet, even with success in producing sufficient food, globally, food insecurity will remain a serious issue in some regions and countries where per capita food consumption will remain inadequate [7].

Global incomes are expected to rise substantially by 2050, yet areas of notable poverty will persist in some countries, particularly in sub-Saharan Africa. The per capita annual income in 2050 likely will remain below $\$ 1000$ in 15 of the 98 lower income countries examined by Alexandratos and Bruinsma [7]. Average daily food consumption might remain below $2700 \mathrm{kcal}$ per person in 16 of the 98 countries. Those 16 countries will be home to a population of 800 million. By comparison, an estimated 4.7 billion people (52\% of global population) will live in countries with national daily averages of more than $3000 \mathrm{kcal}$ per person in 2050, up from 1.9 billion (28\%) in 2011 [7].

Estimates of the increase in food production required to ensure food security in 2050, from the global perspective, range from $60 \%$ to $100 \%$ above the production achieved in 2005 [17]. Those proportions are notably higher than the rate of increase in population to 2050 , due largely to the increasing demands and changing preferences for food, that come with higher incomes. Household and per capita food consumption will increase in many countries, and many residents will consume more meat and vegetables. Those commodities, particularly beef, generally require more water and other productive inputs than grains, per calorie of food consumed [18]. The increasing demand for meat will place additional pressure on limited water resources in some regions. The projected increases in food demand, when realized, will reflect substantial improvement in food and nutritional security for those households with sufficient income to afford adequate food supplies.

As in the present, much of the food and nutritional insecurity that persists in 2050 will be found largely in poor households in countries with lower gross incomes and in areas where depleted or degraded natural resources no longer support viable livelihood activities for smallholders. The primary cause of food insecurity will be the persistent poverty that prevents households from gaining access to sufficient food and nutrition, particularly during periods of notable scarcity and high prices. Thus, the policies and investments most likely to enhance food security will be those that promote economic growth and increase incomes, particularly in rural areas, where many of the world's poor are engaged in agriculture. Substantial public and private-sector investments and policy interventions are needed between now and 2050, particularly in agriculture, to reduce poverty, increase incomes, and ensure food security for all.

The extent and severity of food insecurity in 2050 likely will correspond to the extent and depth of dollar-based poverty. In 2007, an estimated $47 \%$ of the world's poor earning less than $\$ 1.25$ per day lived in South Asia, while 31\% and 17\% lived in sub-Saharan Africa and South Asia and the Pacific, respectively [19]. Just $2.3 \%$ of the world's poor earning less than $\$ 1.25$ per day lived in Latin America and the Caribbean. Projecting future poverty levels and geographic distribution is imprecise, given the many factors that influence livelihoods and incomes. Edward and Sumner [20] examine several scenarios reflecting alternative assumptions regarding economic growth. They suggest that the number of poor earning less than $\$ 2.00$ per day might increase or decline by 2030 , yet they do not expect extreme poverty to be eradicated. In their most optimistic scenario, 300 million persons will live in extreme poverty in 2030. 
The authors suggest also that even if the number of poor earning less than $\$ 2.00$ per day decreases, the number of moderately poor persons might increase. In their view, it is likely that $50 \%$ to $70 \%$ of the global population in 2030 might earn less than $\$ 10$ per day.

\subsection{Water Resources}

The volume of water withdrawn for irrigation, globally, will increase from 2.6 billion $\mathrm{km}^{3}$ in 2005-2007 to an estimated 2.9 billion $\mathrm{km}^{3}$ in 2050, with most of the net increase occurring in lower income countries [21,22]. The irrigation requirement (i.e., the consumptive use portion of irrigation withdrawals) is estimated to increase from 1.27 billion $\mathrm{km}^{3}$ to 1.34 billion $\mathrm{km}^{3}$. Generally, there are sufficient freshwater resources to support this modest increase, although substantial water scarcity will persist in the Near East and North Africa, South Asia, and elsewhere. Water scarcity will intensify in areas where current rates of surface water and groundwater withdrawals are not sustainable, such as the North China Plain and portions of Central and South Asia [23-25].

Many analysts have suggested there will be sufficient water to produce the food needed in 2050 to support a global population of 9 to 10 billion, provided we allocate and manage water wisely, and we achieve notable gains in agricultural productivity [12,26-28]. Wise allocation and use involves understanding the role of water in crop and livestock production, and also in municipal, commercial, and industrial uses, and in the provision of ecosystem services. The demands for water will continue increasing with the size of the global population, with rising incomes, and with successful efforts to extend water supply and sanitation to all residents of urban and rural areas, particularly in lower income countries.

Meeting these increasing demands will require that policy makers provide effective leadership in communicating water scarcity conditions, allocating developed water supplies appropriately, encouraging wise use in all sectors, and conveying accurate perspectives regarding opportunities to enhance the broad spectrum of benefits obtained from water in productive and environmental uses. In countries with substantial numbers of smallholder farmers, policy makers must ensure access to land and water for agricultural households, whose livelihoods and food security are closely linked to the small amounts of land and water they utilize in producing crops and raising livestock.

Water scarcity will constrain agricultural production and livelihood activities in many additional areas in 2050, as the demands for water in agriculture and other sectors continue to increase. Land and water allocation between sectors will become an increasingly challenging political decision, with notable social and economic implications, as cities expand into agricultural areas, and as commerce and industry require additional water supplies. Smallholder farmers in peri-urban areas will be at risk of losing access to land and water to support their agricultural livelihoods. Persistent work is needed in policy and investment arenas, particularly in lower income countries, to extend and ensure access to water for household use and agricultural production. 


\section{Issues and Challenges}

\subsection{Urbanization}

The rate of growth in global population is slowing, yet the population will continue increasing for many years, in both rural and urban areas. Projections suggest that the global population will reach 9 to 10 billion, before stabilizing and eventually declining. The declining rate of growth, in aggregate, will reduce to some degree the demand pressures on land and water resources [7]. Yet, local and regional resource issues will remain important and will require critical attention, particularly in countries where population growth remains strong, and where food insecurity persists. The proportion of the population living in urban areas in China has increased from $17 \%$ in 1978 to $50 \%$ in 2010 , thus requiring the conversion of large areas of farmland during years of notable growth in population and in aggregate food demand [29].

Most of the net increase in global population between 2015 and 2050 will occur in urban areas of lower income countries. The increasing urbanization in many regions and the potential impacts of climate change on crop and livestock production add urgency to the question of whether or not food demands will be met in sustainable fashion. It is also essential that the food produced in 2050 is accessible and affordable to everyone, in the interest of achieving national and household food security in all countries.

Increasing urbanization will impact the volume and quality of water available for agriculture, particularly in peri-urban areas [30]. Substantial public and private investments in wastewater capture, treatment, and reuse will be needed to protect public health and to utilize both the water and the nutrients in effluent streams. As cities expand and urban populations increase, it will become increasingly important to capture the nitrogen, phosphorus, and other plant nutrients in wastewater, and to use those nutrients again in agriculture. Efforts to ensure that farmers in peri-urban areas retain access to water for irrigation will be needed, also, particularly when efforts to collect and treat wastewater are implemented.

Technological advances for capturing and treating wastewater in rural areas of lower income countries will improve water quality and enhance the safety and effectiveness of wastewater irrigation, particularly on smallholder farms [31]. Research regarding business models for generating income through the collection, treatment, and sale of wastewater products will encourage private companies to provide wastewater service in areas not served by public collection and treatment programmes [32-35]. Public agencies also can provide initial funding for entrepreneurs wishing to start new businesses in effluent collection, treatment, and processing, either as sole proprietors or in the form of public-private partnerships [36,37].

\subsection{Agriculture and Rural Poverty}

Even with increasing urbanization, much of the global population, and many of the poor, will live in rural areas and earn their living in agriculture in 2050 . The rural population will decline by about $50 \%$ in China by 2050 , while declining by just $9 \%$ in India, and increasing by $49 \%$ in Ethiopia (Table 1). Across Africa, the rural population will increase by $48 \%$, while decreasing by $8 \%$ in South Asia and by $20 \%$ in Southeast Asia. Globally, the rural population will decline by just $7 \%$ by 2050 (Table 1). Thus, investments in agriculture in lower income countries will be remain critical in raising incomes of the poor and enabling them to achieve household food and nutritional security. 
Table 1. Rural population projections for selected countries and regions, 2015 to 2050.

\begin{tabular}{lccccc}
\hline & $\mathbf{2 0 1 5}$ & $\mathbf{2 0 2 5}$ & $\mathbf{2 0 3 5}$ & $\mathbf{2 0 5 0}$ \\
\cline { 2 - 6 } & \multicolumn{5}{c}{ (million persons) } \\
\hline Country & & & & \\
$\quad$ Ethiopia & 81 & 98 & 111 & 121 \\
& India & 862 & 891 & 875 & 782 \\
$\quad$ China & 628 & 507 & 421 & 318 \\
\hline Region & & & & \\
$\quad$ Africa & 688 & 804 & 906 & 1015 \\
$\quad$ South Asia & 1182 & 1229 & 1213 & 1092 \\
$\quad$ Southeast Asia & 335 & 327 & 309 & 267 \\
\hline World & 3367 & 3381 & 3333 & 3118 \\
\hline
\end{tabular}

Source: Food and Agriculture Organization of the United Nations, FAOSTAT [38].

Smallholder crop and livestock production contributes directly to household and national food security by enhancing home consumption and providing a source of affordable food in local and regional markets $[39,40]$. Smallholder production provides households with the income needed to purchase the crop and livestock products they do not produce. Income also can be saved, as cash or in the form of durable assets, for purchasing food in years when crop production is impaired by inadequate rainfall. Savings are needed also when local food prices rise sharply, due to disruptions in local or international markets. Income from crop production also enables households to purchase meat and vegetables, thus enhancing household nutrition.

Smallholder agriculture is evolving along somewhat different trajectories in Africa and Asia, although the starting points also are quite different. Changes in the average farm size in both regions are determined largely by rural population density, as most rural residents engage in agriculture, and the amount of land available is essentially fixed [41]. Hazell [42] projects that the average annual growth rate in the rural population of Africa will slow from 2.8\% during 1990 to 2010, to 1.35\% from 2011 to 2030, and to just $0.63 \%$ from 2030 to 2050 . By contrast, the projected average annual growth rates in the rural population of Asia are $-0.35 \%$ for 2011 to 2030 and $-0.83 \%$ for 2030 to 2050 . These represent a substantial decline from the rate of $0.32 \%$ observed from 1990 to 2010 . Thus, the average farm size in Asia likely will begin increasing, while the average farm size in Africa will continue to decline through 2050 [41].

In all areas, smallholders will become linked more closely with commercial traders and market chains, although the pace and degree of such interactions will vary notably across countries and regions. This will create both opportunities and challenges for smallholder farmers with limited experience interacting in formal markets. The increasing demand for agricultural output in both domestic and international markets should provide the impetus for public and private sector efforts to increase the productivity of crop and livestock production. Substantial investments are needed, particularly in Africa, where perpetually low rates of fertilizer application and inappropriate soil management practices have resulted in nutrient mining of farm soils for many years [43,44]. Sanchez and Swaminathan [45] have characterized the "crisis in soils" in Africa as a "quiet catastrophe" that has evolved over decades.

The impacts of climate change might be particularly severe on smallholders, given their limited adaptation opportunities. Small households with limited finance and little or no access to irrigation might be forced to seek new livelihood activities if the changes in temperature and rainfall preclude them from continuing 
to grow crops and raise livestock. Policy makers must evaluate both the global and local implications of climate change, while considering also the differing impacts on large farms and smallholders, as they select interventions that will ensure food security for smallholders engaged in crop, livestock, and fish production.

\subsection{Water Use in Agriculture}

Agriculture will continue to be the largest user of developed water resources in most countries, often accounting for $70 \%$ or more of water withdrawals from rivers, reservoirs, and aquifers. Increasing demands for water in cities and industries, and for environmental flows, will reduce the volume of water available for agriculture in many areas. Yet, globally, the volume of water transpired in crop and livestock production must increase between now and 2050, if we are to increase food production. Farmers in many regions must adapt to having less water available for irrigation, while facing increasing demands for their products. Innovations in technology and investments in education and training with regard to managing water in both irrigated and rainfed settings are needed to achieve sustainable agricultural production.

Several authors have suggested that agriculture must "produce more food with less water" in future, given the increasing demands for water in competing sectors [28]. While compelling at first read, this phrase is not sufficiently precise, as it does not distinguish between the water diverted and applied to farm fields, and the water transpired in the process of generating crop yields. Much of the water applied in irrigation runs off the ends of farm fields or percolates into shallow groundwater, where it is available for use again in irrigation or for some other purpose. Only the water consumed by crops in the process of transpiration, and the water that evaporates from plant and soil surfaces, are "lost" from the system at this point in the hydrologic cycle. Opportunities for saving water through investments in technology are limited by the extent to which water is lost in each setting.

The distinction between water diverted and water transpired is important when considering water requirements for food production. The relationship between crop yield or biomass and the amount of water transpired is largely linear for a given cultivar and production setting [46-48]. Thus, in a given setting, absent a technological advance, higher yields can be generated only by transpiring more water. Similarly, more water will be transpired in agriculture as planted areas are expanded in pursuit of higher aggregate production. Advances in crop production technology, including genetic enhancement, can modify the yield-transpiration relationship, such that more output is produced per unit of water transpired. Yet, absent major advances in technology, the amount of water transpired in agriculture will increase between now and 2050.

The water required to support additional transpiration in 2050 can come from several sources, including new development of surface water and groundwater resources for use in agriculture, and better efforts to capture and re-apply surface runoff and utilize shallow groundwater directly in crop production [49-51]. Farmers also can reduce evaporation and improve distribution uniformity by replacing surface irrigation methods with drip systems and micro-sprinklers, where feasible [52], and they can minimize transpiration by non-beneficial plants by removing vegetation from irrigation canals. Such efforts to optimize water use are consistent with the notion of sustainable agricultural intensification, in which higher yields are achieved with given resources, while reducing negative impacts on the environment and enhancing natural capital [52]. 
Competing demands in other sectors and public demands for environmental amenities will limit the amount of new development of surface water and groundwater for agriculture in many regions. Yet, many farmers can improve water management in ways that reduce non-beneficial evaporation and increase the portion of applied water that is transpired beneficially by crops. Farmers also can increase the amount of crop yield obtained per unit of water transpired by assuring that other essential inputs are available in adequate supply. Agricultural productivity generally is higher when high-quality seeds, soil moisture, plant nutrients, and farm chemicals are applied in sufficient amounts and at the appropriate times during the season.

\subsection{Climate Change}

The potential impacts of climate change influence the outlook regarding future gains in agricultural productivity. Some production areas will become warmer and drier, while others will receive more annual rainfall, although the timing of the additional rainfall might not be optimal from a seasonal crop production perspective [53]. Some regions likely will experience reductions in agricultural output, particularly in arid areas where water supplies already are limited. Other areas might experience beneficial changes in cropping patterns and increases in crop yields, with warmer temperatures and longer growing seasons [54-56]. Higher concentrations of $\mathrm{CO}_{2}$ will increase the yields of $\mathrm{C}_{3}$ crops (e.g., wheat, rice, barley, sugarbeets, and cotton) in some areas, while higher ozone concentrations will have an offsetting, negative impact in others [57]. In large countries such as China and India, the impacts of climate change and the appropriate policy responses and investments could vary substantially across production regions [56,58-60].

Livestock systems also are subject to potentially substantial impacts of climate change, with notable implications for food security and welfare, particularly in lower income countries [61-64]. Sustained high temperatures can impair livestock health and productivity, directly, while water shortages and higher ozone levels in the atmosphere can reduce the yields of livestock feed [65-68]. The potential impacts of climate change might be substantial in the livestock sector, as grazing and mixed rain-fed systems account for $70 \%$ of all ruminants and two-thirds of the milk and meat they produce, worldwide [65].

The net effects of climate change on crop and livestock production will influence efforts to achieve national food security in some countries. Poor residents of lower income countries are particularly vulnerable to climate-change induced impairment of food security, given their limited ability to modify production and consumption activities [69]. Rainfed production, which accounts for $80 \%$ of global cropland and $60 \%$ of global food output, might be notably affected by climate change, particularly in arid and semi-arid areas [70]. Yet, efforts to mitigate or adapt to climate change should not preclude interventions that increase crop yields and improve farm incomes in the near term. Successful efforts to increase fertilizer use in Africa and to reduce groundwater overdraft on the Indo-Gangetic Plain are needed urgently, yet they might increase the variance in farm output in a climate change scenario [71].

Climate change also can impact the availability and quality of both surface water and groundwater, with implications for agricultural production and for associated ecosystems. The increasing variability in rainfall can influence the flow of water in surface systems and the rates of recharge and discharge from aquifers [72,73]. Currently, an estimated 38\% of the global irrigated area depends on groundwater [74]. 
Further research is needed to describe more fully the potential effects of climate change on groundwater dependent ecosystems, yet the impacts are thought to be larger in arid regions, on shallow aquifers, and on ecosystems already stressed in advance of climate change [72,75]. Improvements in the representation of groundwater systems in river basin models that normally highlight surface water, will enhance understanding of climate change impacts, given the importance of groundwater system characteristics in determining the number and duration of droughts [76-78].

Further study of interactions involving groundwater withdrawals, irrigation, and climate change will provide insight for policy makers considering adaptation strategies. Ferguson and Maxwell [79] show that the impacts of irrigation on groundwater storage and stream discharge in a semi-arid basin in the southern United States are quite similar to the simulated impacts of a $2.5{ }^{\circ} \mathrm{C}$ rise in temperature. The implications of this research, as described by the authors, are twofold: (1) Many semi-arid basins in which groundwater supports irrigation might already be experiencing some of the potential impacts of climate change; and (2) The actual impacts of climate change might be exacerbated by the additional stress placed on aquifers that support irrigation. Thus, policy makers might need to regulate groundwater pumping in semi-arid irrigated basins.

The increased frequency of major weather events and unexpected changes in weather patterns, brought about by climate change, might also cause more frequent occurrence of crop failures in key production regions, causing short-term reductions in food supplies and consequent price increases, as happened in 2008 and 2011. Given this likelihood, some degree of coordination among countries in establishing regional grain reserves that could be released in times of production shortfalls might limit the harmful effects of higher food prices on poor households during periods of regional crop failure. The cost of maintaining such a reserve might be shared by both importing and exporting countries.

National governments and donors must continue investing in measures that enhance adaptation to climate change at both regional and household levels, such as water storage structures, conjunctive use of groundwater and surface water, wastewater capture and reuse, and research that generates more resilient production systems for smallholders. Policy makers must also protect and sustain the upland areas and mountainous regions where much of the world's water supply originates.

\subsection{Protecting Water Resources}

In several key production regions, water resources are over-exploited or degraded in ways that are not sustainable. In large areas of South and East Asia, including northwestern India and the North China Plain, groundwater withdrawals exceed the rates of natural recharge, and aquifers are in decline [23,80,81]. Millions of households depend on water for production in such regions, and yet the over-exploitation cannot continue indefinitely [82]. Policy interventions are needed urgently, to achieve the necessary reductions in water withdrawals in a planned and gradual manner, while assisting households in pursuing alternative livelihood activities. Investments in groundwater treatment and pollution reduction also are needed, as many residents depend on groundwater for drinking and other household uses [83].

Improvements in irrigation efficiency in northwestern India and on the North China Plain will not be sufficient to eliminate the overdraft of groundwater, if the aggregate consumptive use of water continues to exceed the natural rate of recharge [23]. Reductions in consumptive use can be achieved by growing crops 
that require less water per season and by reducing the area planted, yet such efforts will reduce household net income and impact the regional economy. Irrigation supplies can be augmented somewhat by capturing and utilizing rainfall that, otherwise, would evaporate, yet the potential net gains from such activity are limited [23]). In areas where substantial rainfall occurs only in short seasons, efforts to capture more of the water in aquifers, for use later in the year might enhance irrigation and other water-dependent activities during the dry season [84].

Groundwater use in agriculture and other sectors has increased substantially since the middle 20th century, and in many areas, annual groundwater withdrawals exceed the rate of natural recharge. Global groundwater withdrawals in humid to semi-arid areas have increased from an estimated $312 \mathrm{~km}^{3}$ per year in 1960 to an estimated $734 \mathrm{~km}^{3}$ per year in 2006. As a result, groundwater depletions have increased from an estimated $126 \mathrm{~km}^{3}$ per year in 1960 to an estimated $283 \mathrm{~km}^{3}$ per year in 2006 [85]. Most of the increased withdrawals and depletion are attributed to the increasing use of groundwater for irrigation, in response to rising demands for agricultural output.

Technological advances during the 1950s through the 1980s, including high-capacity pumps and affordable, small-scale pumps and tubewells, also facilitated the rapid increase in groundwater pumping across large areas of North America, South Asia, and northern China [86-90]. Grogan et al. [91] find that groundwater mining accounts for $20 \%$ to $49 \%$ of gross irrigation water demand in a large portion of China, assuming all demand is met. Given this estimate, the authors suggest that $15 \%$ to $27 \%$ of China's current crop production is made possible by mining groundwater. Subsidized energy prices have contributed to the increase in groundwater pumping in South Asia [92]. Policy makers must consider issues pertaining to water, energy, and food production in a comprehensive manner, to determine the optimal plan for regulating groundwater pumping, while minimizing unintended impacts.

Optimizing the conjunctive use of surface water and groundwater will enhance the sustainability of irrigated agriculture in many regions, particularly in areas where excessive withdrawals cause costly increases in groundwater pumping depths, or the return flows from agriculture degrade water quality in receiving streams [87,93,94]. Siderius et al. [95] demonstrate the economic viability of conjunctively managing groundwater and rainfall in a tank irrigation system in Andhra Pradesh, India. The higher yields obtained of rice, groundnuts, and sugarcane generate sufficient revenue to offset the cost of rehabilitating the tank system at the start of the six-year experiment, while providing substantial net income per hectare of irrigated land.

Shah [96] reviews India's Groundwater Recharge Master Plan, designed to raise groundwater levels in the post-monsoon season to three meters below ground level. The programme will involve annual "managed artificial recharge" of $36.4 \mathrm{~km}^{3}$ of water, using an estimated four million spreading-type recharge structures. While commending the intent of the ambitious recharge programme, the author recommends greater focus on the most depleted basins, while also utilizing the 11 million private dug wells already constructed by Indian farmers. In addition, Shah [96] recommends revising energy tariffs to encourage farm-level support for the groundwater recharge programme.

As in many areas of India, farmers in the Indus River Basin of Pakistan practice a de facto form of conjunctive use, as they utilize many small wells for irrigation, in combination with canal water deliveries [97]. Farm-level benefits vary with location along each delivery canal, as farmers located further from a turnout rely more on groundwater than do farmers located more closely. Access to groundwater provides many farmers with a higher degree of security regarding their water supply and 
enables them to optimize the timing of irrigation events. Thus, crop yields and cropping intensities generally are enhanced in groundwater zones. However, some degree of coordination will be required to prevent salinization of farm soils [97], which can impair agricultural productivity and degrade water quality in rivers and shallow aquifers.

The ability to monitor and analyze changes in groundwater levels has been notably enhanced in recent years with the development of satellite-based gravitational techniques for measuring changes in aquifer storage. Many researchers have used data gathered by the Gravity Recovery and Climate Experiment (GRACE), a multi-year research programme funded jointly by the United States and Germany, to characterize changes in aquifer storage in Africa, Asia, the Middle East, Australia, and in North and South America [98-106]. The characterizations, made possible by satellite coverage, are particularly helpful to water resource analysts and policy makers in regions where conventional data describing changes in aquifer storage are not readily available.

\section{Policies and Investments}

\subsection{Technology for Sustainable Agriculture}

Much has been learned in the last 50 years, regarding the role of technology in improving water management, increasing crop yields, and enhancing farm incomes. Many farmers in arid and semi-arid regions have adopted drip and sprinkler irrigation systems, while many also laser level their fields, and many deliver fertilizer via their on-farm irrigation systems in a process known as fertigation [107-109]. Optimizing the use of water and nutrients in crop production, planting hybrid varieties of some crops, using higher quality seeds, and implementing new methods of pest control, have contributed to the large and sustained increases in crop yields observed in many countries since the 1960s and 1970s [110-113].

Genetic improvements in crop varieties also have increased household incomes and enhanced food security in some areas. The adoption of Bt cotton production by smallholders in central and southern India has enabled households to consume larger amounts of more nutritious foods, thus generally improving their dietary status [114]. Other countries also are exploring the potential for increasing agricultural output with genetically improved crops. The National Technical Committee on Crop Biotechnology in the Ministry of Agriculture of Bangladesh has approved the import of Golden Rice, fruit-and shoot-borer resistant Bt eggplant, late blight resistant potato, insect resistant Bt chickpea, and ring spot virus resistant papaya for contained trials [115].

In Sri Lanka, micro-propagation via tissue culture of an improved banana variety has enabled smallholder rice farmers to diversify their cropping pattern and earn additional income [116]. Kabunga et al. [117] observed similar results in a survey of 385 diversified smallholder farming households in the Central and Eastern Provinces of Kenya. Farmers adopting tissue culture technology for vegetative propagation of bananas increased their farm and household incomes by $116 \%$ and $86 \%$, respectively, due largely to higher net yields and beneficial adjustments in the mix of inputs. Food security was improved through higher incomes and larger amounts of bananas for home consumption.

Agriculture can benefit also from advances in technology that do not involve genetic enhancement. Advances in biotechnology can improve the detection and control of plant diseases, while biofertilizers and biopesticides can enhance plant nutrition and pest control [118]. Similar advances are available for 
use in livestock production and in aquaculture. Molecular-based serological techniques have notably improved animal health in lower income countries, while molecular-based pathogen detection systems are used to detect viruses in all countries producing commercial shrimp [118].

Continuous investment in research and development of technologies that will enhance smallholder crop, livestock, and fish production is essential. Improvements in crop and livestock genetics, and in production techniques that enable farmers to increase production with limited land and water resources are needed by smallholders, along with supporting investments in education, training, and outreach. Private sector investments and public-private partnerships will enhance the pace at which new technologies are developed and implemented.

\subsection{Investing in Rainfed and Irrigated Production}

The remarkable increases in agricultural productivity achieved since the 1960s have enabled farmers in many countries to produce sufficient food to support the world's population as it has increased from about 3 billion in 1960 to more than 7 billion in 2015. Much of the gain in aggregate output has been achieved through the expansion of planted area, while much has come also from higher yields. Much of the additional food production required by 2050 must come from further increases in crop and livestock yields, given the high costs and environmental impacts of continuing to expand agricultural area. Further investments in both rainfed and irrigated areas are needed to ensure that crop and livestock yields will continue increasing at a pace that is sufficient to feed a global population of 9 to 10 billion in 2050 .

Irrigated agriculture accounts for about $20 \%$ of cultivated area, worldwide, while generating an estimated $40 \%$ of crop production $[38,119,120]$. Yields are notably higher with irrigation, in part because farmers apply larger amounts of fertilizer and farm chemicals when they have some control over the timing and amount of soil moisture in their fields [121]. Much of the world's food supply in 2050 will come from irrigated farms, yet much will also come from farms that rely fully on rainfall and those that supplement rainfall with partial irrigation. In many countries, achieving national food security in 2050 will require investments and interventions in both irrigated and rainfed areas.

Substantial research has been conducted in recent years on methods for improving water management in rainfed areas, such as rainwater harvesting, plant nutrient strategies, cropping systems, mulching, tillage, and other soil and water conservation practices [122,123]. Efforts to extend improved methods of farming in rainfed conditions will improve incomes and enhance livelihoods in areas where poverty is correlated with low crop yields and inadequate use of fertilizer and modern seeds [11,124].

Advances in agricultural technology will enable many farmers to increase production in rainfed and irrigated settings. Yet, technology, alone, will not be sufficient to completely offset limitations regarding land, water, and other natural resources. Accurate water accounting and water balance studies will be needed in many areas to identify the most appropriate interventions for increasing agricultural productivity with limited water supplies. In addition, public officials must support efforts to ensure that farmers have affordable access to complementary inputs, such as high-quality seeds, plant nutrients, and farm chemicals.

\subsection{Closing the Yield Gaps}

Continuous public investments are needed in the development of new technology and in technical assistance to support smallholder crop, livestock, and aquaculture production. Many rural households 
will remain engaged in agriculture in 2050 , and their production will contribute to local and regional food supplies, while also enhancing household incomes. Closing the large gaps that exist between smallholder yields and those obtained on larger farms and experiment stations will serve both to increase food supply and enhance effective demand for food at household and community levels. New crop varieties, better methods of producing current varieties, and enhanced outreach by crop and livestock extension specialists are needed.

Evidence in the literature regarding the challenge of closing yield gaps is mixed $[125,126]$. The annual rate of increase in crop yields is slowing in key production areas, causing concern that future gains might not keep pace with rate of increase in global food demand [127,128]. Some authors suggest that improvements in soil and water management, facilitated in part by more affordable access to farm inputs in lower income countries, will be helpful in closing the existing yield gaps across a large portion of the world's agricultural landscape [129,130]. The potential yield gaps likely are larger in rainfed settings than in irrigated areas, yet the challenges of increasing yields in rainfed areas also are substantial $[131,132]$. In either setting, the desired increases in yield will take time, and progress will not be uniform, as outcomes will vary with soil and water conditions and with access to fertilizer [133,134]. Li et al. [135] report that wheat yields on the North China Plain have increased by about $115 \mathrm{~kg}$ per ha per year, since 1981, thus substantially closing the farm-level yield gap. However, they report also that wheat yields are no longer increasing in some areas.

Other authors suggest that advances in plant genetics, agronomy, biotechnology, and animal science will provide the improvements needed in crop and livestock technology to achieve further increases in yields [136-144]. However, some authors question whether the needed advances can be developed, tested, and implemented broadly within the time available between now and 2050 [145]. Substantial public investments in crop and livestock science are needed to move research programmes forward, particularly those that largely will benefit smallholders [146]. However, even with adequate financial support, substantial time will be required for producing new cultivars with traits that meet both global and farm-level objectives [147].

Livestock production and marketing are essential livelihood components for more than one billion poor persons in Asia and Africa [148]. Many of these persons are smallholders, for whom livestock represent a source of food and income, while serving also as a means for accumulating wealth. The increasing global demand for livestock products will create opportunities for smallholders to generate higher incomes, provided they have access to output markets and to the inputs and capital needed to expand their operations in sustainable fashion, while maintaining risk at acceptable levels [149,150].

\subsection{Seeking Sustainability}

While the potential for increasing crop and livestock yields and improving rural livelihoods through investments in technology, education, and outreach is substantial, continuous effort is needed also in developing agricultural practices and enterprises that manage natural resources wisely and do not impose excessive harm on the environment. The agriculture that thrives in 2050 and beyond must adapt to changes in weather patterns brought about by climate change, to changes in public preferences regarding environmental amenities, and to changes in food demands due to increasing incomes and changing 
demographics. This is no small order for a sector that involves much of the world's developed land and water resources, and still engages a large portion of the global population.

Some authors have characterized the quest for this new agricultural paradigm as that of seeking "sustainable intensification" or pursuing "climate-smart agriculture." Both phrases, as they are described in the literature, reflect the need to ensure the long-term viability of agriculture, with due consideration for natural resources, the environment, and climate change [151]. The first phrase also acknowledges the need to enhance productivity in future, by increasing the use of farm inputs in ways that have less impact on the environment than in current or earlier production settings. Both phrases express ideas, rather than providing a clear statement of the investments and changes in practices that a programme of sustainable intensification or climate-smart agriculture would require. Thus, the phrases are helpful in generating discussion, but they do not, by themselves, provide guidelines for achieving production outcomes that are sustainable or climate smart.

In a recent review of the sustainable intensification debate, Godfray [152] suggests that the perspective has stimulated helpful discussion of alternative agricultural models, yet further work in defining the production practices that are considered acceptable within the paradigm would provide greater clarity. Uphoff [153] urges caution in selecting specific practices before considering the notions of sustainability and intensification within a systems thinking perspective, and accounting more explicitly for the inherent inability to predict which practices and production models might actually be sustainable.

Garnett et al. [154] describe four premises supporting the sustainable intensification perspective: (1) Agricultural production must increase to achieve global food security goals; (2) Higher yields are essential to minimize environmental harm due to land expansion; (3) Protecting the environment is as important as increasing agricultural productivity; and (4) Achieving sustainable intensification is a goal, rather than a well-defined plan of action. The authors suggest also that sustainable intensification embeds goals pertaining to food and nutritional security, and sustainable economic development. Hanspach et al. [155] propose inverting that relationship by placing initial emphasis on achieving sustainable development, given that food insecurity is due largely to inadequate incomes, rather than the lack of food production. Vanlauwe et al. [156] suggest that sustainable intensification might not be pertinent in much of sub-Saharan Africa, where the average farm size is too small to intensify, and where many farmers must place the issues of risk and immediacy ahead of longer-term concerns. "Ultimately, the profitability of intensification will determine whether or not smallholders engage - its sustainability will not necessarily be their immediate concern [156]."

Scholarly discussion of sustainable intensification and climate-smart agriculture, in addition to reports from development practitioners, will add clarity to both perspectives, over time $[151,157,158]$. Successful efforts to ensure food and nutritional security in future, in sustainable fashion, must reflect the inherent complexities regarding agriculture, the environment, and livelihoods, and the notable heterogeneity in farm structures and opportunities in rainfed, irrigated, large-scale, and smallholder settings [159]. The characteristics of sustainable, climate resilient agriculture likely will be different in each setting. The time and investments required to achieve sustainable intensification, where appropriate, also will vary with initial conditions and with expected case-specific outcomes, as viewed by farmers, as they are impacted most directly when implementing the recommended practices. 


\subsection{Capturing and Reusing Plant Nutrients}

The large yields of grains and other crops achieved in many countries, are made possible, in part, by the application of large amounts of nitrogen and other plant nutrients each season. Plants utilize much of the applied nutrients in the process of carbon assimilation, yet some portion of the nutrients enter the atmosphere, runoff in streams, or seep into groundwater. The portion taken up by plants is conveyed to processing plants and dining rooms, and eventually to the wastewater stream leaving households, villages, and cities. As urbanization intensifies in many areas, and as the direct and indirect costs of nutrient use in agriculture increase, over time, the need to recycle the water and plant nutrients in municipal wastewater will become more evident and more urgent.

The cost of producing nitrogen fertilizer depends largely on the price of energy, as the process is energy intensive. Although energy prices have declined sharply in 2014 and 2015, it is likely that energy prices will resume their long-term upward trend in the not-too-distant future. Phosphorus is an essential plant nutrient that is produced largely by mining phosphate rock [160]. The supply of phosphate rock is ultimately limited and large portions of the remaining supply are located in just a few countries [161-164]. Thus, there is some uncertainty regarding the security of newly mined supplies of phosphorus in future. Recycling the phosphorus in wastewater will extend the useful life of existing phosphate rock reserves, by reducing the demand for that source of phosphorus. There are mixed views in the literature, regarding if or when the world might exhaust its supply of phosphate rock [165]. An enhanced wastewater recycling programme, in which phosphorus, nitrogen, and other elements are obtained and reused, likely would be a wise hedging strategy from a global perspective.

There is also a sense of circularity or ecosystem closure in the notion of returning plant nutrients to farmland in the countryside, after food has been consumed in the city. The recovered nutrients can be used again to produce more food, and the cycle can be repeated. In addition, efforts to extend and intensify the capture and reuse of wastewater will reduce the negative environmental impacts of unregulated wastewater discharge into rivers and streams. In areas where the economics of wastewater recovery and reuse are positive, and local governments encourage private firms to engage in the activity for profit, wastewater management can become a widely acknowledged business enterprise that generates sustainable benefits for households, communities, and farmers [35]. The health risks to farmers, households, and consumers can be managed through appropriate policy interventions [166,167].

\subsection{Investing in Sustainable Aquaculture}

Fisheries and aquaculture are major sources of protein for much of the world's population, and the sectors support many livelihoods in both formal and informal economies [168]. An estimated 3 billion persons obtain about $20 \%$ of their intake of animal protein from the output of a capture fishery or an aquaculture operation [169]. An additional 1.3 billion persons obtain 15\% of their protein intake from fish. These proportions represent averages across many countries. For individual countries, the shares can be much higher. In Gambia, Sierra Leone, and Ghana, the share of dietary protein from fish is higher than $60 \%$ [169]. The share ranges from 50\% to 60\% in Cambodia, Bangladesh, Indonesia, and Sri Lanka, where capture fisheries have long been important, and where aquaculture has developed rapidly since the 1990s [169]. 
Aquaculture currently generates more than $50 \%$ of the fish and shellfish products consumed worldwide [170,171]. More than $60 \%$ of global aquaculture production comes from China, while an additional $26 \%$ of production comes from other countries in southern and eastern Asia [171]. The Americas and Europe each account for about $4 \%$ of global aquaculture production, while Africa accounts for about $2 \%$ of the global sum. Although production in Africa is presently a small portion of global output, the rate of growth in African production has been quite high in recent years. African production has increased from about 81,000 tons in 1990 to 1.4 million tons in 2012, thus increasing by a factor of 18 within 22 years [171]. By comparison, China's production in 2012 (41 million tons) is about 6 times higher than its production in 1990 (6.7 million tons).

Across Africa, aquaculture employs about 920,000 persons and accounts for 0.15 percent of Gross Domestic Product [172]. These are small portions of the employment and income generated by both fisheries and aquaculture in Africa. The full sector employs about 12 million persons and generates annual income of about $\$ 24$ billion, or $1.26 \%$ of African gross domestic income [172]. Yet, for the persons involved in small-scale aquaculture, often in conjunction with small-scale farming, the additional production and income enhance household food and nutritional security [173]. The increasing demand for fish and fish products in Africa presents a substantial opportunity for further expansion of small-scale, commercial aquaculture.

Fisheries and aquaculture provide livelihoods for many smallholders, often in conjunction with other activities, such as rice production, in which farmers utilize land and water for both fish and crops. In some areas, aquaculture competes with agriculture for water supply, and it impacts agriculture by degrading land and water quality. These and other environmental issues, including the use of fishmeal and fish oil as feed materials, and the off-site impacts of effluent from aquaculture operations will require policy intervention to ensure that aquaculture can continue contributing to global food and nutrition demands in a sustainable fashion.

\subsection{Investing in Risk Management}

Investments in agriculture and water, and policies designed to encourage wise use of resources, must recognize also the inherent risk and uncertainty in farming, particularly in smallholder settings, and also the potential impacts of climate change. Smallholders often are prevented from adopting new technologies or utilizing the appropriate amounts of farm inputs because they cannot risk losing their investment in expensive seeds or irrigation water if a dry spell or pest infestation destroys their crop. Programmes of crop insurance and access to affordable credit can assist in such situations, but they do not fully eliminate the farm-level risk.

Crop yields are determined in large part by the amounts of seeds or plants applied to each hectare, and the amounts of water, fertilizer, and chemicals used each season. Yet, yields also are influenced by weather, pests, and the timing by which inputs are applied. Farmers can manage the effects of weather and pests, to some degree, and they can choose the timing by which they apply key inputs, yet much of the resulting influence on crop yields is uncertain. The yield obtained in one season by applying $20 \mathrm{~kg}$ of seed, $100 \mathrm{~kg}$ of nitrogen, and $600 \mathrm{~mm}$ of irrigation water on a hectare of grain can be quite different from the yield achieved with the same inputs in a subsequent season, due largely to influences that farmers cannot control. 
The nature of risk and uncertainty, and the degree of farm-level risk aversion vary across farms, with differences in farmer perspectives, household savings, access to crop insurance, crop choices, weather patterns, and market conditions. Perhaps the largest distinction is between farmers in higher income countries, with substantial savings accounts and crop insurance, and smallholder farmers in lower income countries with very limited savings and no access to insurance. The latter farmers often will limit their use of costly inputs, such as high-quality seeds and plant nutrients, as inadequate rainfall or a serious pest infestation can cause them to lose their entire expenditure. Smallholders can manage risk to some degree by diversifying their crop choices, but opportunities are limited in areas with very much or too little rainfall [174,175]. Interventions that assist farmers in accommodating risk, such as index-based weather insurance, can be helpful in improving household income and welfare in such settings [176].

Investments and programmes that enhance agricultural risk management, particularly for smallholders, will be critical in enabling farm households to adopt new technologies, diversify their activities, and sustain food security during periods of high input prices, low crop yields, and major weather events. In addition to insurance products, investments are needed also in infrastructure that enhances the availability and transport of farm inputs and crop and livestock products, and reduces the transaction costs of marketing farm produce. Such investments will increase the values that farmers generate with limited water resources, while also enhancing household food and nutritional security.

\subsection{Investing in Water, Sanitation, and Health}

Many poor households have inadequate access to clean water and sanitation. As a result, many women and children spend substantial time and effort fetching water for household use, and family members often suffer from ill health, caused by unclean or unsanitary living conditions. Such illness, and the time spent fetching and preparing water for use, reduce educational opportunities and limit labor productivity. Securing access to an affordable, safe water source can greatly enhance a household's likelihood of escaping poverty, by enabling family members to devote more time and effort to educational and productive activities.

Many rural households also lack secure title to the land and water they use to produce crops and raise livestock, as part of their essential livelihood activities. Many smallholders operate in rainfed settings, in which the crop water supply is inherently uncertain. Small reservoirs are helpful in capturing and storing rainwater for use in households or on crops, as needed, but not all farm households can afford such an investment, due partly to the cost of installation and partly to the opportunity cost of setting land aside from crop production. Efforts to assist farmers in constructing small reservoirs and training farmers to optimize rainwater harvesting would be helpful in many areas. Where water is available from an irrigation scheme or a wastewater treatment facility, many smallholders might benefit from assistance in securing a permanent or long-term right to receive some portion of the available water. Long-term security in land and water will motivate smallholders to invest in improving their crop, livestock, and aquaculture operations, as funds allow, over time.

In many areas of low-income countries, an investment in water can be viewed also as an investment in poverty reduction. The need for investments in water supply, water treatment, irrigation, drainage, flood control, and rainwater harvesting is quite large in many countries. Investors in the water sector can generate substantial improvements in livelihoods and greatly enhance the welfare of households, and 
communities across much of Africa and Asia. Yet, investments must be carefully planned, and they must account for many of the interactions and externalities that are inherent in water development projects. In many settings, the development of an irrigation scheme or construction of a rainwater harvesting structure in one location will enhance water supply for one set of users, while impairing the water supply for others. The impairment might be direct, in terms of the volume or flow of water available in an aquifer or stream, or it might be indirect, in the form of reduced flows to an estuary that supports an indigenous fishery or provides plant materials that are harvested each season by residents who produce crafts for sale in local markets. The best investments in water resources, from a poverty reduction perspective, will be those that enhance the volume and quality of water available for household use and production, while minimizing impacts on other water users and the environment.

Investments in drinking water supply, water quality, sanitation, and health care, with a particular focus on women and children, are essential to ensure that residents of urban and rural areas can fully utilize available food and nutrition, while not suffering from chronic diseases and other impairments that reduce household welfare and limit educational and productive opportunities. Good health is essential to successful utilization, and successful growth and development are essential to productivity, income generation, and food security. This virtuous cycle revolves around assured access to affordable clean water, sanitation, and health facilities.

\subsection{Investing in Rural Economies}

Many residents of rural areas earn income in non-farm activities. This is particularly true of landless households and women. Rural households with little or no land earn from $30 \%$ to $90 \%$ of their income in non-farm employment, while women account for one-quarter of the workforce in the rural non-farm economy lower income countries [177]. Households with insufficient land to rise above the poverty line in farming typically account for about half of rural families [178]. Most of the rural, non-farm households in lower income countries are poor, and in high density rural areas, most of the poor are landless or have too little land to support them in agriculture [178]. For those households, non-farm employment and viable opportunities for producing and selling non-tradable goods and services are essential.

Many farm households rely on income from non-farm employment to supplement farm income, and as a source of finance for farm inputs [177]. An estimated $65 \%$ of smallholder farmers in Latin America and the Caribbean rely increasingly on non-farm source of incomes to sustain their livelihoods [179]. The non-farm economy employs family members not needed to work full-time in smallholder farming operations. As the rural population density increases, so too does the importance of non-farm employment in providing livelihood opportunities for households with surplus labor, either seasonally or year-round. Quantifying the impact of non-farm employment on poverty reduction is challenging, due to inadequate data and the difficulty of identifying causality in environments where many macroeconomic variables change with time. Yet, it appears non-farm employment has accounted for substantial poverty reduction in some countries [177].

Further work is needed to determine with accuracy the impacts of non-farm employment on poverty reduction, and the impacts of agricultural growth on the non-farm economy. However, it is likely that the success of commercially oriented smallholder farmers will lead to greater expenditures on non-tradable 
goods and services in the rural non-farm sector, thus enhancing economic activity and providing new employment opportunities. This will reduce poverty and improve food security in rural areas [178].

Several authors in recent years have provided empirical evidence of the impacts of non-farm employment on household income and food security. In a survey of 220 farm households in Nigeria, Babatunde and Qaim [180] found that off-farm employment contributes to higher incomes, thus enabling greater consumption of calories and micronutrieints. Opportunities to earn off-farm income also significantly improved child height-for-age statistics in the villages in which the authors conducted their survey.

Kumanayake et al. [181] show that as rural households in Sri Lanka shifted from farm to non-farm sources of income, between 1990 and 2006, they became less poor. Education played a role in the ability of farm households to gain employment in the non-farm sector in Sri Lanka. Investments in education in rural areas can lead to greater participation in the non-farm economy, with consequent improvement in household welfare.

Wossen and Berger [182], combined large-scale survey data with information collected from 292 randomly selected households in northern Ghana, in a simulation of the potential impacts of access to off-farm employment opportunities and improved access to financial credit on poverty and food security. The authors determined that households with access to credit and off-farm employment can increase their incomes substantially and enhance their food security, particularly when subject to climate and price variability.

Imai et al. [183], using aggregate data collected in national household surveys in India and Vietnam, identified significant reductions in poverty and in vulnerability to shocks, for rural households engaged in non-farm employment. In addition, the authors report that employment in skilled jobs, such as in sales or professional activities, has a more notable impact on poverty and vulnerability than does employment in unskilled jobs, such as those involving manual labor. Thus, in India and Vietnam, while any form of non-farm employment is helpful in reducing household poverty and vulnerability, employment in skilled jobs is most desirable.

Policies and investments that enhance opportunities for off-farm employment in rural areas will increase incomes, reduce poverty, and enhance food security, particularly in areas where land and water resources are inadequate to support higher population densities. Higher incomes are essential to achieving food security, and in many rural areas, those higher incomes must come from new opportunities in off-farm employment.

\subsection{Investing in Women}

Much of the farming in Asia and Africa is conducted by women [38]. Yet, women often do not share the same status as men, regarding such issues as land tenure, water rights, access to credit, participation in outreach programmes, and representation in water user associations [184-186]. It is essential that the status of women be improved, so they may achieve the same degree of access as men, to the tenure, credit, and other inputs needed to produce and market crops successfully.

Efforts are needed also to encourage and support the role of women in agricultural research, extension, and teaching, and as representatives in farmer groups and marketing cooperatives. As agriculture intensifies and as new marketing opportunities arise for smallholders in lower income countries, interventions and 
investments must enhance the critical role of women in production and marketing activities. Policies and institutions must also acknowledge the role of women in the allocation of household income, with implications for food and nutritional security, and educational opportunities for children $[148,186]$. Engaging and empowering women in deliberative processes pertaining to climate change will enhance the resulting policies and interventions [187,188].

Several studies provide empirical evidence of gender aspects of crop production and marketing. Ndiritu et al. [189], in a survey involving 578 farm households in Kenya, find that women manage smaller plots than men, and they are less likely to adopt some sustainable intensification practices, such as manure application and minimum tillage. The authors find no gender differences in the adoption of other soil and water conservation practices, such as maize-legume intercropping, maize-legume rotations, improved seed varieties, and the use of chemical fertilizer. Such findings, while not fully explained, suggest that further work is needed to understand gender differences in the adoption of selected intensification practices.

The commercialization of smallholder agriculture provides opportunities for farmers to earn and retain higher revenues, as they gain access to a wider array of markets for their produce. One way in which smallholders can advance their participation in new markets is by forming cooperatives or farmer groups that interact in markets on behalf of the membership. Forming and joining farmer groups can modify crop choices and the distribution of farm income within households, if the representation and status of men and women in such groups are different. Fischer and Qaim [190] examine this issue, using data pertaining to banana production in the highlands of central Kenya.

Tissue culture propagation of bananas, in combination with a new mix of productive inputs, has enabled farmers in Kenya to achieve higher yields, thus providing the opportunity to expand their sales in commercial markets. Many smallholders have joined farmer groups that interact with potential buyers, and sell large lots of bananas at collectively negotiated prices. Membership in the groups is individual, and both men and women may join, yet the elected leadership generally is male dominated [190].

Using data from a survey of 444 member and non-member farm households, Fischer and Qaim [190] test hypotheses regarding the impacts of farmer groups on crop production and revenue, women's control of farm revenues, and household nutrition. The authors find that farmer groups tend to increase male control of banana production and revenues. This does not influence the number of calories consumed in the household, but it does have a negative marginal impact on dietary quality, perhaps due to differences in male and female spending preferences. Most notably, female membership in the groups can have a positive impact on the share of income controlled by women.

There are notable gender differences, also, in the formation and productivity of rural non-farm enterprises. In a study of survey data collected by the World Bank in Bangladesh, Ethiopia, Indonesia, and Sri Lanka, Rijkers and Costa [191] find that women are less likely than men to start a non-farm enterprise (with the exception of Ethiopia), women's enterprises tend to be small and home based, and firms operated by women are less productive, as measured by sales per worker (with the exception of Indonesia). Male managers generally are better educated than female managers, yet the authors do not find evidence that differences in human capital account for gender differences in firm performance. The authors also find no support for the hypothesis that gender productivity differences are due differential gender impacts in the local investment climate [191]. Further work is needed to understand fully the gender aspects of the rural non-farm economy in lower income countries. 
Although women are responsible for much of the farming in Asia and Africa, many of the institutional settings that influence agriculture are not supportive of women's role in the sector. More appropriate institutions, supportive policies, and strategic investments are needed to enhance the role and success of women in agriculture, particularly in production, but also in research, education, and outreach. Policies that enhance women's security of land tenure, water rights, access to credit, and representation in water user associations and farmer cooperatives are essential. So, too, are programmes that encourage women to enter careers in agricultural research, extension, and teaching.

\subsection{Water Policy, Institutions, and Incentives}

With increasing competition for water in agriculture and other sectors, national and provincial governments will need to communicate water scarcity conditions effectively, and ensure that farmers, firms, and consumers use water wisely. They must also allocate water with the right mix of concerns for equity and efficiency. Economists often promote pricing as an effective mechanism for communicating scarcity conditions. Yet, pricing water often is difficult to implement, for political or cultural reasons, and water tariffs can be difficult to modify, once in place [192-194]. Nonetheless, it is helpful to consider water prices as a policy option, alongside other interventions, such as water allocations, withdrawal limits, pumping restrictions, rotational deliveries, and cropping pattern restrictions.

In areas where implementing higher prices is not yet politically feasible, public officials might consider implementing water allocations. Such an approach can be just as effective in communicating scarcity conditions, as a programme involving higher water prices. When the volume of water available in a river basin or irrigation district is limited, the aggregate volume can be divided among water users by assigning to each a pro-rated portion of that volume. When farmers know their water supply is limited, they have an incentive to optimize the values they obtain with the amount of water they receive.

Incentive programmes can encourage water users to improve water management practices in both irrigated and rainfed settings. In agriculture, public support for investments in land leveling and the purchase of drip or micro-sprinkler systems can be helpful, where appropriate, although such investments might not result in aggregate water savings. Industries also respond positively to subsidies for investments in water-saving processes and in wastewater capture and reuse. Such programmes are helpful, also, when implementing higher water prices. The higher prices modify the incremental price of water as desired, while the subsidies can limit the increase in the total cost of adjusting to higher water prices, from the water user's perspective.

\section{Conclusions}

Water resources and food production will be sufficient to support a global population of 9 to 10 billion in 2050, but many of the poor will struggle to retain access to water for household use and production, and many will remain food insecure. The primary cause of food insecurity will continue to be poverty, rather than inadequate food production. Thus, policy makers need to implement programs and encourage investments that will increase the incomes of the poor. Public and private investments that promote growth in sustainable agriculture and provide non-farm employment opportunities in rural areas of lower income countries will be most helpful. 
Policy makers must ensure that farmers retain access to the water they need for producing food and sustaining livelihoods, particularly as increasing urbanization places additional pressure on land and water resources. They must create greater opportunities for women in agriculture, and they must motivate the development and adoption of new technologies that will enhance crop and livestock production, particularly for smallholders. Private sector investments also are essential to speed the pace of creating viable employment opportunities in rural areas. Public officials must communicate scarcity conditions by implementing the right mix of pricing policies, resource allocations, and incentives. Finally, all policies and investments must also account for the likely impacts of climate change on agriculture and on the livelihoods of smallholders.

\section{Acknowledgments}

I appreciate the helpful comments and suggestions received from scholars at the Food and Agriculture Organization of the United Nations and several other institutes engaged in research, outreach, and development activities. I am grateful also for the helpful comments of three anonymous reviewers.

\section{Conflicts of Interest}

The author declares no conflict of interest.

\section{References}

1. Cabero-Roura, L.; Rushwan, H. An update on maternal mortality in low-resource countries. Int. J. Gynecol. Obstet. 2014, 125, 175-180.

2. Cohen, R.L.; Alfonso, Y.N.; Adam, T.; Kuruvilla, S.; Schweitzer, J.; Bishai, D. Country progress towards the Millennium Development Goals: Adjusting for socioeconomic factors reveals greater progress and new challenges. Glob. Health 2014, 10, 1-19.

3. Lomazzi, M.; Borisch, B.; Laaser, U. The Millennium Development Goals: Experiences, achievements, and what's next. Glob. Health Action 2014, 7 (Suppl. 1), 1-7.

4. Dora, C.; Haines, A.; Balbus, J.; Fletcher, E.; Adair-Rohani, H.; Alabaster, G.; Hossain, R.; de Onis, M.; Branca, F.; Neira, M. Indicators linking health and sustainability in the post-2015 development agenda. Lancet 2015, 385, 380-391.

5. Maurice, J. New goals in sight to reduce poverty and hunger. Lancet 2013, 382, 383-384.

6. United Nations. Report of the Open Working Group of the General Assembly on Sustainable Development Goals. Issued as document A/68/970, United Nations, 2014. Available online: http://undocs.org/A/68/970 (accessed on 12 April 2015).

7. Alexandratos, N.; Bruinsma, J. World Agriculture towards 2030/2050: The 2012 Revision; ESA Working paper No. 12-03; FAO: Rome, Italy, 2012.

8. Ray, D.K.; Mueller, N.D.; West, P.C.; Foley, J.A. Yield trends are insufficient to double global crop production by 2050. PLoS ONE 2013, 8, e66428, doi:10.1371/journal.pone.0066428.

9. Furbank, R.T.; Tester, M. Phenomics-Technologies to relieve the phenotyping bottleneck. Trends Plant Sci. 2011, 16, 635-644. 
10. Afari-Sefa, V.; Tenkouano, A.; Ojiewo, C.O.; Keatinge, J.D.H.; Hughes, J.D.A. Vegetable breeding in Africa: Constraints, complexity and contributions toward achieving food and nutritional security. Food Secur. 2012, 4, 115-127.

11. Dzanku, F.M.; Jirström, M.; Marstorp, H. Yield gap-based poverty gaps in rural sub-Saharan Africa. World Dev. 2015, 67, 336-362.

12. Grafton, R.Q.; Williams, J.; Jiang, Q. Food and water gaps to 2050: Preliminary results from the global food and water system (GFWS) platform. Food Secur. 2015, 7, 209-220.

13. Rivers, J.; Warthmann, N.; Pogson, B.J.; Borevitz, J.O. Genomic breeding for food, environment and livelihoods. Food Secur. 2015, 7, 375-382.

14. Koning, N.B.J.; van Ittersum, M.K.; Becx, G.A.; van Boekel, M.A.J.S.; Brandenburg, W.A.; van den Broek, J.A.; Goudriaan, J.; van Hofwegen, G.; Jongeneel, R.A.; Schiere, J.B.; et al. Long-term global availability of food: Continued abundance or new scarcity. NJAS Wagening. J. Life Sci. 2008, 55, 229-292.

15. Koning, N.; van Ittersum, M.K. Will the world have enough to eat? Curr. Opin. Environ. Sustain. 2009, 1, 77-82.

16. McKenzie, F.C.; Williams, J. Sustainable food production: Constraints, challenges and choices by 2050. Food Secur. 2015, 7, 221-233.

17. Bruinsma, J. The Resource Outlook to 2050: By How Much do Land, Water and Crop Yields Need to Increase by 2050? FAO Expert Meeting on How to Feed the World in 2050; Food and Agriculture Organization: Rome, Italy, 2009.

18. Eshel, G.; Shepon, A.; Makov, T.; Milo, R. Land, irrigation water, greenhouse gas, and reactive nitrogen burdens of meat, eggs, and dairy production in the United States. Proc. Natl. Acad. Sci. USA 2014, 111, 11996-12001.

19. Sumner, A. Where Do The Poor Live? World Dev. 2012, 40, 865-877.

20. Edward, P.; Sumner, A. Estimating the scale and geography of global poverty now and in the future: How much difference do method and assumptions make? World Dev. 2014, 58, 67-82.

21. Bruinsma, J. The resources outlook: By how much do land, water and crop yields need to increase by 2050? In Looking Ahead in World Food and Agriculture: Perspectives to 2050; Conforti, P., Ed.; Food and Agriculture Organization: Rome, Italy, 2011.

22. FAO. The State of the World's Land and Water Resources for Food and Agriculture (SOLAW): Managing Systems at Risk; FAO: Rome, Italy; Earthscan: London, UK, 2011.

23. Zheng, C.; Liu, J.; Cao, G.; Kendy, E.; Wang, H.; Jia, Y. Can China cope with its water crisis? -Perspectives from the North China Plain. Ground Water 2010, 48, 350-354.

24. Biemans, H.; Speelman, L.H.; Ludwig, F.; Moors, E.J.; Wiltshire, A.J.; Kumar, P.; Gerten, D.; Kabat, P. Future water resources for food production in five South Asian river basins and potential for adaptation-A modeling study. Sci. Total Environ. 2013, 468, S117-S131.

25. Karthe, D.; Chalov, S.; Borchardt, D. Water resources and their management in central Asia in the early twenty first century: Status, challenges and future prospects. Environ. Earth Sci. 2014, 73, 487-499.

26. De Fraiture, C.; Molden, D.; Wichelns, D. Investing in water for food, ecosystems, and livelihoods: An overview of the comprehensive assessment of water management in agriculture. Agric. Water Manag. 2010, 97, 495-501. 
27. De Fraiture, C.; Wichelns, D. Satisfying future water demands for agriculture. Agric. Water Manag. 2010, 97, 502-511.

28. Springer, N.P.; Duchin, F. Feeding nine billion people sustainably: Conserving land and water through shifting diets and changes in technologies. Environ. Sci. Technol. 2014, 48, 4444-4451.

29. Liu, L.; Xu, X.; Chen, X. Assessing the impact of urban expansion on potential crop yield in China during 1990-2010. Food Secur. 2015, 7, 33-43.

30. Qadir, M.; Wichelns, D.; Raschid-Sally, L.; McCornick, P.G.; Drechsel, P.; Bahri, A.; Minhas, P.S. The challenges of wastewater irrigation in developing countries. Agric. Water Manag. 2010, 97, 561-568.

31. Kim, M.; Lee, H.; Kim, M.; Kang, D.; Kim, D.; Kim, Y.; Lee, S. Wastewater retreatment and reuse system for agricultural irrigation in rural villages. Water Sci. Technol. 2014, 70, 1961-1968.

32. Murray, A.; Cofie, O.; Drechsel, P. Efficiency indicators for waste-based business models: Fostering private-sector participation in wastewater and faecal-sludge management. Water Int. 2011, 36, 505-521.

33. Wichelns, D.; Drechsel, P. Meeting the challenge of wastewater irrigation: Economics, finance, business opportunities and methodological constraints. Water Int. 2011, 36, 415-419.

34. Scott, C.A.; Raschid-Sally, L. The global commodification of wastewater. Water Int. 2012, 37, $147-155$.

35. Otoo, M.; Drechsel, P.; Hanjra, M.A. Business models and economic approaches for nutrient recovery from wastewater and fecal sludge. In Wastewater: Economic Asset in an Urbanizing World; Drechsel, P., Qadir, M., Wichelns, D., Eds.; Springer: Berlin/Heidelberg, Germany, 2015; Chapter 13, pp. 247-270.

36. Murray, A.; Mekala, G.D.; Chen, X. Evolving policies and the roles of public and private stakeholders in wastewater and faecal-sludge management in India, China and Ghana. Water Int. 2011, 36, 491-504.

37. Amerasinghe, P.; Bhardwaj, R.M.; Scott, C.; Jella, K.; Marshall, F. Urban wastewater and agricultural reuse challenges in India. IWMI Res. Rep. 2013, 147, 1-28.

38. FAO. FAOSTAT; FAO: Rome, Italy, 2015.

39. Tscharntke, T.; Clough, Y.; Wanger, T.C.; Jackson, L.; Motzke, I.; Perfecto, I.; Vandermeer, J.; Whitbread, A. Global food security, biodiversity conservation and the future of agricultural intensification. Biol. Conserv. 2012, 151, 53-59.

40. High Level Panel of Experts (HLPE). Investing in Smallholder Agriculture for Food Security. A Report by the High Level Panel of Experts on Food Security and Nutrition of the Committee on World Food Security; High Level Panel of Experts (HLPE): Rome, Italy, 2013.

41. Masters, W.A.; Djurfeldt, A.A.; de Haan, C.; Hazell, P.; Jayne, T.; Jirström, M.; Reardon, T. Urbanization and farm size in Asia and Africa: Implications for food security and agricultural research. Glob. Food Secur. 2013, 2, 156-165. 
42. Hazell, P. Comparative Study of Trends in Urbanization and Changes in Farm Size in Africa and Asia: Implications for Agricultural research. A Foresight Study of the Independent Science and Partnership Council. Available online: http://ispc.cgiar.org/publications/search?field_ publication_date_value_1[value][year] $=2013 \&$ combine $=$ Changes + in + Farm + Size $($ accessed on 3 February 2015).

43. Bekunda, M.; Sanginga, N.; Woomer, P.L. Restoring soil fertility in sub-saharan Africa. Adv. Agron. 2010, 108, 183-236.

44. Kamau, M.; Smale, M.; Mutua, M. Farmer demand for soil fertility management practices in Kenya's grain basket. Food Secur. 2014, 6, 793-806.

45. Sanchez, P.A.; Swaminathan, M.S. Hunger in Africa: The link between unhealthy people and unhealthy soils. Lancet 2005, 365, 442-444.

46. Zwart, S.J.; Bastiaanssen, W.G.M. Review of measured crop water productivity values for irrigated wheat, rice, cotton and maize. Agric. Water Manag. 2004, 69, 115-133.

47. Tolk, J.A.; Howell, T.A. Field water supply: Yield relationships of grain sorghum grown in three USA Southern Great Plains soils. Agric. Water Manag. 2008, 95, 1303-1313.

48. Steduto, P.; Hsiao, T.C.; Raes, D.; Fereres, E. AquaCrop-The FAO crop model to simulate yield response to water: I. Concepts and underlying principles. Agron. J. 2009, 101, 426-437.

49. Clemmens, A.J.; Allen, R.G.; Burt, C.M. Technical concepts related to conservation of irrigation and rainwater in agricultural systems. Water Resour. Res. 2008, 44, W00E03, doi:10.1029/ 2007WR006095.

50. Ayars, J.E.; Shouse, P.; Lesch, S.M. In situ use of groundwater by alfalfa. Agric. Water Manag. 2009, 96, 1579-1586.

51. Satchithanantham, S.; Krahn, V.; Sri Ranjan, R.; Sager, S. Shallow groundwater uptake and irrigation water redistribution within the potato root zone. Agric. Water Manag. 2014, 132, 101-110.

52. FAO. Save and Grow: A Policy Maker's Guide to the Sustainable Intensification of Smallholder Crop Production; FAO: Rome, Italy, 2011.

53. Roudier, P.; Sultan, B.; Quirion, P.; Berg, A. The impact of future climate change on West African crop yields: What does the recent literature say? Glob. Environ. Chang. 2011, 21, 1073-1083.

54. Kang, Y.; Khan, S.; Ma, X. Climate change impacts on crop yield, crop water productivity and food security-A review. Prog. Nat. Sci. 2009, 19, 1665-1674.

55. Gerardeaux, E.; Giner, M.; Ramanantsoanirina, A.; Dusserre, J. Positive effects of climate change on rice in Madagascar. Agron. Sustain. Dev. 2012, 32, 619-627.

56. Zhou, L.; Turvey, C.G. Climate change, adaptation and China's grain production. China Econ. Rev. 2014, 28, 72-89.

57. Jaggard, K.W.; Qi, A.; Ober, S. Possible changes to arable crop yields by 2050. Philos. Trans. $R$. Soc. B 2010, 365, 2835-2851.

58. Chauhan, B.S.; Prabhjyot, K.; Mahajan, G.; Randhawa, R.K.; Singh, H.; Kang, M.S. Global warming and its possible impact on agriculture in India. Adv. Agron. 2014, 123, 65-121.

59. Wei, T.; Cherry, T.L.; Glomrød, S.; Zhang, T. Climate change impacts on crop yield: Evidence from China. Sci. Total Environ. 2014, 499, 133-140. 
60. Xiong, W.; Holman, I.; Lin, E.; Conway, D.; Jiang, J.; Xu, Y.; Li, Y. Climate change, water availability and future cereal production in China. Agric. Ecosyst. Environ. 2010, 135, 58-69.

61. Thornton, P.K.; van de Steeg, J.; Notenbaert, A.; Herrero, M. The impacts of climate change on livestock and livestock systems in developing countries: A review of what we know and what we need to know. Agric. Syst. 2009, 101, 113-127.

62. Herrero, M.; Thornton, P.K. Livestock and global change: Emerging issues for sustainable food systems. Proc. Natl. Acad. Sci. USA 2013, 110, 20878-20881.

63. Godber, O.F.; Wall, R. Livestock and food security: Vulnerability to population growth and climate change. Glob. Chang. Biol. 2014, 20, 3092-3102.

64. Headey, D.; Taffesse, A.S.; You, L. Diversification and development in pastoralist Ethiopia. World Dev. 2014, 56, 200-213.

65. Nardone, A.; Ronchi, B.; Lacetera, N.; Ranieri, M.S.; Bernabucci, U. Effects of climate changes on animal production and sustainability of livestock systems. Livest. Sci. 2010, 130, 57-69.

66. Nielsen, A.; Steinheim, G.; Mysterud, A. Do different sheep breeds show equal responses to climate fluctuations? Basic Appl. Ecol. 2013, 14, 137-145.

67. Megersa, B.; Markemann, A.; Angassa, A.; Ogutu, J.O.; Piepho, H.-P.; Valle Zaráte, A. Impacts of climate change and variability on cattle production in southern Ethiopia: Perceptions and empirical evidence. Agric. Syst. 2014, 130, 23-34.

68. Morignat, E.; Perrin, J.-B.; Gay, E.; Vinard, J.; Calavas, D.; Hénaux, V. Assessment of the impact of the 2003 and 2006 heat waves on cattle mortality in France. PLOS ONE 2014, 9, e93176, doi:10.1371/journal.pone.0093176.

69. High Level Panel of Experts (HLPE). Food Security and Climate Change. A Report by the High Level Panel of Experts on Food Security and Nutrition of the Committee on World Food Security; High Level Panel of Experts (HLPE): Rome, Italy, 2012.

70. Turral, H.; Burke, J.; Faurès, J.M. Climate Change, Water and Food Security. FAO Water Reports 36; Food and Agriculture Organization: Rome, Italy, 2011.

71. Lobell, D.B. Climate change adaptation in crop production: Beware of illusions. Glob. Food Secur. 2014, 3, 72-76.

72. Kløve, B.; Ala-Aho, P.; Bertrand, G.; Gurdak, J.J.; Kupfersberger, H.; Kværner, J.; Muotka, T.; Mykrä, H.; Preda, E.; Rossi, P.; et al. Climate change impacts on groundwater and dependent ecosystems. J. Hydrol. 2014, 518, 250-266.

73. Kurylyk, B.L.; MacQuarrie, K.T.B.; McKenzie, J.M. Climate change impacts on groundwater and soil temperatures in cold and temperate regions: Implications, mathematical theory, and emerging simulation tools. Earth Sci. Rev. 2014, 138, 313-334.

74. Siebert, S.; Henrich, V.; Frenken, K.; Burke, J. Update of the Global Map of Irrigation Areas to Version 5; FAO: Rome, Italy, 2013.

75. Menberg, K.; Blum, P.; Kurylyk, B.L.; Bayer, P. Observed groundwater temperature response to recent climate change. Hydrol. Earth Syst. Sci. 2014, 18, 4453-4466.

76. Van Lanen, H.A.J.; Wanders, N.; Tallaksen, L.M.; van Loon, A.F. Hydrological drought across the world: Impact of climate and physical catchment structure. Hydrol. Earth Syst. Sci. 2013, 17, 1715-1732. 
77. Van Loon, A.F.; Tijdeman, E.; Wanders, N.; van-Lanen, H.A.J.; Teuling, A.J.; Uijlenhoet, R. How climate seasonality modifies drought duration and deficit. J. Geophys. Res. 2014, 119, 4640-4656.

78. Wanders, N.; van Lanen, H.A.J. Future discharge drought across climate regions around the world modelled with a synthetic hydrological modelling approach forced by three general circulation models. Nat. Hazards Earth Syst. Sci. 2015, 15, 487-504.

79. Ferguson, I.M.; Maxwell, R.M. Human impacts on terrestrial hydrology: Climate change versus pumping and irrigation. Environ. Res. Lett. 2012, 7, 044022, doi:10.1088/1748-9326/7/4/044022.

80. Tiwari, V.M.; Wahr, J.; Swenson, S. Dwindling groundwater resources in northern India, from satellite gravity observations. Geophys. Res. Lett. 2009, 36, L18401, doi:10.1029/2009GL039401.

81. Glazer, A.N.; Likens, G.E. The water table: The shifting foundation of life on land. Ambio 2012, 41, 657-669.

82. Shah, T. The groundwater economy of south Asia: An assessment of size, significance and socio-ecological impacts. In The Agricultural Groundwater Revolution: Opportunities and Threats to Development; Giordano, M., Villholth, K., Eds.; CAB International: Wallingford, UK, 2007.

83. Qiu, J. China to spend billions cleaning up groundwater. Science 2011, 334, 745, doi:10.1126/ science.334.6057.745.

84. Khan, M.R.; Voss, C.I.; Yu, W.; Michael, H.A. Water resources management in the Ganges basin: A comparison of three strategies for conjunctive use of groundwater and surface water. Water Resour. Manag. 2014, 28, 1235-1250.

85. Wada, Y.; van Beek, L.P.H.; van Kempen, C.M.; Reckman, J.W.T.M.; Vasak, S.; Bierkens, M.F.P. Global depletion of groundwater resources. Geophys. Res. Lett. 2010, 37, L20402, doi:10.1029/ 2010 GL044571.

86. Qureshi, A.S.; McCornick, P.G.; Qadir, M.; Aslam, Z. Managing salinity and waterlogging in the Indus Basin of Pakistan. Agric. Water Manag. 2008, 95, 1-10.

87. Shah, T. Climate change and groundwater: India's opportunities for mitigation and adaptation. Environ. Res. Lett. 2009, 4, 1-13.

88. Zhang, L.; Wang, J.; Huang, J.; Huang, Q.; Rozelle, S. Access to groundwater and agricultural production in China. Agric. Water Manag. 2010, 97, 1609-1616.

89. Green, T.R.; Taniguchi, M.; Kooi, H.; Gurdak, J.J.; Allen, D.M.; Hiscock, K.M.; Treidel, H.; Aureli, A. Beneath the surface of global change: Impacts of climate change on groundwater. J. Hydrol. 2011, 405, 532-560.

90. Shi, J.; Wang, Z.; Zhang, Z.; Fei, Y.; Li, Y.; Zhang, F.; Chen, J.; Qian, Y. Assessment of deep groundwater over-exploitation in the North China Plain. Geosci. Front. 2011, 2, 593-598.

91. Grogan, D.S.; Zhang, F.; Prusevich, A.; Lammers, R.B.; Wisser, D.; Glidden, S.; Li, C.; Frolking, S. Quantifying the link between crop production and mined groundwater irrigation in China. Sci. Total Environ. 2015, 511, 161-175.

92. Shah, T.; Giordano, M.; Mukherji, A. Political economy of the energy-groundwater nexus in India: Exploring issues and assessing policy options. Hydrogeol. J. 2012, 20, 995-1006.

93. Shah, T. Towards a managed aquifer recharge strategy for Gujarat, India: An economist's dialogue with hydro-geologists. J. Hydrol. 2014, 518, 94-107.

94. Singh, A. Conjunctive use of water resources for sustainable irrigated agriculture. J. Hydrol. 2014, 519, 1688-1697. 
95. Siderius, C.; Boonstra, H.; Munaswamy, V.; Ramana, C.; Kabat, P.; van Ierland, E.; Hellegers, P. Climate-smart tank irrigation: A multi-year analysis of improved conjunctive water use under high rainfall variability. Agric. Water Manag. 2015, 148, 52-62.

96. Shah, T. India's master plan for groundwater recharge: An assessment and some suggestions for revision. Econ. Political Wkly. 2008, 43, 41-49.

97. Kazmi, S.I.; Ertsen, M.W.; Asi, M.R. The impact of conjunctive use of canal and tube well water in Lagar irrigated area, Pakistan. Phys. Chem. Earth 2012, 47, 86-98.

98. Frappart, F.; Seoane, L.; Ramillien, G. Validation of GRACE-derived terrestrial water storage from a regional approach over South America. Remote Sens. Environ. 2013, 137, 69-83.

99. Jin, S.; Feng, G. Large-scale variations of global groundwater from satellite gravimetry and hydrological models, 2002-2012. Glob. Planet. Chang. 2013, 106, 20-30.

100. Lenk, O. Satellite based estimates of terrestrial water storage variations in Turkey. J. Geodyn. 2013, 67, 106-110.

101. Famiglietti, J.S.; Rodell, M. Water in the balance. Science 2013, 340, 1300-1301.

102. Voss, K.A.; Famiglietti, J.S.; Lo, M.; de Linage, C.; Rodell, M.; Swenson, S.C. Groundwater depletion in the Middle East from GRACE with implications for transboundary water management in the Tigris-Euphrates-Western Iran region. Water Resour. Res. 2013, 49, 904-914.

103. Ahmed, M.; Sultan, M.; Wahr, J.; Yan, E. The use of GRACE data to monitor natural and anthropogenic induced variations in water availability across Africa. Earth Sci. Rev. 2014, 136, 289-300.

104. Castle, S.L.; Thomas, B.F.; Reager, J.T.; Rodell, M.; Swenson, S.C.; Famiglietti, J.S. Groundwater depletion during drought threatens future water security of the Colorado River Basin. Geophys. Res. Lett. 2014, 41, 5904-5911.

105. Chen, J.; Li, J.; Zhang, Z.; Ni, S. Long-term groundwater variations in Northwest India from satellite gravity measurements. Glob. Planet. Chang. 2014, 116, 130-138.

106. Wang, H.; Guan, H.; Gutiérrez-Jurado, H.A.; Simmons, C.T. Examination of water budget using satellite products over Australia. J. Hydrol. 2014, 511, 546-554.

107. Castellanos, M.T.; Tarquis, A.M.; Ribas, F.; Cabello, M.J.; Arce, A.; Cartagena, M.C. Nitrogen fertigation: An integrated agronomic and environmental study. Agric. Water Manag. 2013, 120, $46-55$.

108. Chai, Q.; Gan, Y.; Turner, N.C.; Zhang, R.-Z.; Yang, C.; Niu, Y.; Siddique, K.H.M. Water-saving innovations in Chinese agriculture. Adv. Agron. 2014, 126, 149-201.

109. Gheysari, M.; Loescher, H.W.; Sadeghi, S.H.; Mirlatif, S.M.; Zareian, M.J.; Hoogenboom, G. Water-yield relations and water use efficiency of maize under nitrogen fertigation for semiarid environments: Experiment and synthesis. Adv. Agron. 2015, 130, 175-229.

110. Biazin, B.; Sterk, G.; Temesgen, M.; Abdulkedir, A.; Stroosnijder, L. Rainwater harvesting and management in rainfed agricultural systems in sub-Saharan Africa: A review. Phys. Chem. Earth 2012, 47, 139-151.

111. Wright, B.D. Grand missions of agricultural innovation. Research Policy 2012, 41, 1716-1728.

112. Stevenson, J.R.; Villoria, N.; Byerlee, D.; Kelley, T.; Maredia, M. Green Revolution research saved an estimated 18 to 27 million hectares from being brought into agricultural production. Proc. Natl. Acad. Sci. USA 2013, 110, 8363-8368. 
113. Alston, J.M.; Pardey, P.G. Agriculture in the global economy. J. Econ. Perspect. 2014, 28, 121-146.

114. Qaim, M.; Kouser, S. Genetically modified crops and food security. PLoS ONE 2013, 8, 1-7.

115. Fahmi, A. Benefits of new tools in biotechnology to developing countries in South Asia: A perspective from UNESCO. J. Biotechnol. 2011, 156, 364-369.

116. Lagoda, P.J.L. Use of tissue culture and mutation inductIon to improve banana productIon for smallholders in Sri Lanka. In Biotechnologies at Work for Smallholders: Case Studies from Developing Countries in Crops, Livestock and Fish; Ruane, J., Dargie, J.D., Mba, C., Boettcher, P., Makkar, H.P.S., Bartley, D.M., Sonnino, A., Eds.; Food and Agriculture Organization: Rome, Italy, 2013.

117. Kabunga, N.S.; Dubois, T.; Qaim, M. Impact of tissue culture banana technology on farm household income and food security in Kenya. Food Policy 2014, 45, 25-34.

118. Ruane, J.; Sonnino, A. Agricultural biotechnologies in developing countries and their possible contribution to food security. J. Biotechnol. 2011, 156, 356-363.

119. Turral, H.; Svendsen, M.; Faurès, J.M. Investing in irrigation: Reviewing the past and looking to the future. Agric. Water Manag. 2010, 97, 551-560.

120. FAO. AQUASTAT, FAO's Global Water Information System; FAO: Rome, Italy, 2015.

121. Monjardino, M.; McBeath, T.M.; Brennan, L.; Llewellyn, R.S. Are farmers in low-rainfall cropping regions under-fertilising with nitrogen? A risk analysis. Agric. Syst. 2013, 116, 37-51.

122. Karpouzoglou, T.; Barron, J. A global and regional perspective of rainwater harvesting insub-Saharan Africa's rainfed farming systems. Phys. Chem. Earth 2014, 72, 43-53.

123. Kurothe, R.S.; Kumar, G.; Singh, R.; Tiwari, S.P.; Vishwakarma, A.K.; Sena, D.R.; Pande, V.C. Effect of tillage and cropping systems on runoff, soil loss and crop yields under semiarid rainfed agriculture in India. Soil Tillage Res. 2014, 140, 126-134.

124. Affholder, F.; Poeydebat, C.; Corbeels, M.; Scopel, E.; Tittonell, P. The yield gap of major food crops in family agriculture in the tropics: Assessment and analysis through field surveys and modelling. Field Crops Res. 2013, 143, 106-118.

125. Waddington, S.R.; Li, X.; Dixon, J.; Hyman, G.; de Vicente, M.C. Getting the focus right: Production constraints for six major food crops in Asian and African farming systems. Food Secur. 2010, 2, 27-48.

126. Sumberg, J. Mind the (yield) gap(s). Food Policy 2012, 4, 509-518.

127. Grassini, P.; Eskridge, K.M.; Cassman, K.G. Distinguishing between yield advances and yield plateaus in historical crop production trends. Nat. Commun. 2013, 4, 2918, doi:10.1038/ ncomms 3918 .

128. Jat, M.L.; Bijay-Singh; Gerard, B. Nutrient management and use efficiency in wheat systems of South Asia. Adv. Agron. 2014, 125, 171-259.

129. Spiertz, H. Avenues to meet food security. The role of agronomy on solving complexity in food production and resource use. Eur. J. Agron. 2012, 43, 1-8.

130. Pasuquin, J.M.; Pampolino, M.F.; Witt, C.; Dobermann, A.; Oberthür, T.; Fisher, M.J.; Inubushi, K. Closing yield gaps in maize production in Southeast Asia through site-specific nutrient management. Field Crops Res. 2014, 156, 219-230. 
131. Lobell, D.B.; Cassman, K.G.; Field, C.B. Crop yield gaps: Their importance, magnitudes, and causes. Annu. Rev. Environ. Resour. 2009, 34, 179-204.

132. Kassie, B.T.; van Ittersum, M.K.; Hengsdijk, H.; Asseng, S.; Wolf, J.; Rötter, R.P. Climate-induced yield variability and yield gaps of maize (Zea mays L.) in the Central Rift Valley of Ethiopia. Field Crops Res. 2014, 160, 41-53.

133. Bryan, B.A.; King, D.; Zhao, G. Influence of management and environment on Australian wheat: Information for sustainable intensification and closing yield gaps. Environ. Res. Lett. 2014, 9, 044005, doi:10.1088/1748-9326/9/4/044005.

134. Connor, D.J.; Mínguez, M.I. Evolution not revolution of farming systems will best feed and green the world. Glob. Food Secur. 2012, 1, 106-113.

135. Li, K.; Yang, X.; Liu, Z.; Zhang, T.; Lu, S.; Liu, Y. Low yield gap of winter wheat in the North China Plain. Eur. J. Agron. 2014, 59, 1-12.

136. Bruce, T.J.A. Tackling the threat to food security caused by crop pests in the new millennium. Food Secur. 2010, 2, 133-141.

137. Powell, N.; Ji, X.; Ravash, R.; Edlington, J.; Dolferus, R. Yield stability for cereals in a changing climate. Funct. Plant Biol. 2012, 39, 539-552.

138. Blum, A. Drought resistance is it really a complex trait? Funct. Plant Biol. 2011, 38, 753-757.

139. Blum, A. Heterosis, stress, and the environment: A possible road map towards the general improvement of crop yield. J. Exp. Bot. 2013, 64, 4829-4837.

140. Cabello, J.V.; Lodeyro, A.F.; Zurbriggen, M.D. Novel perspectives for the engineering of abiotic stress tolerance in plants. Curr. Opin. Biotechnol. 2014, 26, 62-70.

141. Dolferus, R. To grow or not to grow: A stressful decision for plants. Plant Sci. 2014, 229, $247-261$.

142. Rothschild, M.F.; Plastow, G.S. Applications of genomics to improve livestock in the developing world. Livest. Sci. 2014, 166, 76-83.

143. Vadez, V.; Palta, J.; Berger, J. Developing drought tolerant crops: Hopes and challenges in an exciting journey. Funct. Plant Biol. 2014, 41, v-vi.

144. Langridge, P.; Reynolds, M.P. Genomic tools to assist breeding for drought tolerance. Curr. Opin. Biotechnol. 2015, 32, 130-135.

145. Hall, A.J.; Richards, R.A. Prognosis for genetic improvement of yield potential and water-limited yield of major grain crops. Field Crops Res. 2013, 143, 18-33.

146. Anthony, V.M.; Ferroni, M. Agricultural biotechnology and smallholder farmers in developing countries. Curr. Opin. Biotechnol. 2012, 23, 278-285.

147. Spiertz, H. Agricultural sciences in transition from 1800 to 2020: Exploring knowledge and creating impact. Eur. J. Agron. 2014, 59, 96-106.

148. McDermott, J.; Aït-Aïssa, M.; Morel, J.; Rapando, N. Agriculture and household nutrition security: Development practice and research needs. Food Secur. 2013, 5, 667-678.

149. Herrero, M.; Thornton, P.K.; Gerber, P.; Reid, R.S. Livestock, livelihoods and the environment: Understanding the trade-offs. Curr. Opin. Environ. Sustain. 2009, 1, 111-120.

150. Tiwari, R.; Dileep Kumar, H.; Dutt, T.; Singh, B.P.; Pachaiyappan, K.; Dhama, K. Future challenges of food security and sustainable livestock production in India in the changing climatic scenario. Asian J. Anim. Vet. Adv. 2014, 9, 367-384. 
151. Campbell, B.M.; Thornton, P.; Zougmoré, R.; van Asten, P.; Lipper, L. Sustainable intensification: What is its role in climate smart agriculture? Curr. Opin. Environ. Sustain. 2014, 8, 39-43.

152. Godfray, H.C.J. The debate over sustainable intensification. Food Secur. 2015, 7, 199-208.

153. Uphoff, N. Systems thinking on intensification and sustainability: Systems boundaries, processes and dimensions. Curr. Opin. Environ. Sustain. 2014, 8, 89-100.

154. Garnett, T.; Appleby, M.C.; Balmford, A.; Bateman, I.J.; Benton, T.G.; Bloomer, P.; Burlingame, B.; Dawkins, M.; Dolan, L.; Fraser, D.; et al. Sustainable intensification in agriculture: Premises and policies. Science 2013, 341, 33-34.

155. Hanspach, J.; Abson, D.J.; Loos, J.; Tichit, M.; Chappell, M.J.; Fischer, J. Develop, then intensify. Science 2013, 341, 713, doi:10.1126/science.341.6147.713-a.

156. Vanlauwe, B.; Coyne, D.; Gockowski, J.; Hauser, S.; Huising, J.; Masso, C.; Nziguheba, G.; Schut, M.; van Asten, P. Sustainable intensification and the African smallholder farmer. Curr. Opin. Environ. Sustain. 2014, 8, 15-22.

157. Kuyper, T.W.; Struik, P.C. Epilogue: Global Food Security, Rhetoric, and the Sustainable Intensification Debate. Curr. Opin. Environ. Sustain. 2014, 8, 71-79.

158. Struik, P.C.; Kuyper, T.W.; Brussaard, L.; Leeuwis, C. Deconstructing and unpacking scientific controversies in intensification and sustainability: Why the tensions in concepts and values? Curr. Opin. Environ. Sustain. 2014, 8, 80-88.

159. Habel, J.C.; Teucher, M.; Hornetz, B.; Jaetzold, R.; Kimatu, J.N.; Kasili, S.; Mairura, Z.; Mulwa, R.K.; Eggermont, H.; Weisser, W.W.; et al. Real-world complexity of food security and biodiversity conservation. Biodivers. Conserv. 2015, 24, doi:10.1007/s10531-015-0866-z.

160. Johnston, A.E.; Poulton, P.R.; Fixen, P.E.; Curtin, D. Phosphorus: Its efficient use in agriculture. Adv. Agron. 2014, 123, 177-228.

161. Lott, J.N.A.; Kolasa, J.; Batten, G.D.; Campbell, L.C. The critical role of phosphorus in world production of cereal grains and legume seeds. Food Secur. 2011, 3, 451-462.

162. Ryan, J.; Ibrikci, H.; Delgado, A.; Torrent, J.; Sommer, R.; Rashid, A. Significance of phosphorus for agriculture and the environment in the West Asia and North Africa region. Adv. Agron. 2012, 114, 91-153.

163. Cordell, D.; White, S. Life's bottleneck: Sustaining the world's phosphorus for a food secure future. Annu. Rev. Environ. Resour. 2014, 39, 161-188.

164. Cordell, D.; White, S. Tracking phosphorus security: Indicators of phosphorus vulnerability in the global food system. Food Secur. 2015, 7, 337-350.

165. Ziadi, N.; Whalen, J.K.; Messiga, A.J.; Morel, C. Assessment and modeling of soil available phosphorus in sustainable cropping systems. Adv. Agron. 2013, 122, 85-126.

166. Hanjra, M.A.; Blackwell, J.; Carr, G.; Zhang, F.; Jackson, T.M. Wastewater irrigation and environmental health: Implications for water governance and public policy. Int. J. Hyg. Environ. Health 2012, 215, 255-269.

167. Keraita, B.; Medlicott, K.; Drechsel, P.; Mateo-Sagasta Dávila, J. Health risks and cost-effective health risk management in wastewater use systems. In Wastewater: Economic Asset in an Urbanizing World; Drechsel, P., Qadir, M., Wichelns, D., Eds.; Springer: Berlin/Heidelberg, Germany, 2015; Chapter 3, pp. 39-54. 
168. Béné, C.; Barange, M.; Subasinghe, R.; Pinstrup-Andersen, P.; Merino, G.; Hemre, G.-I.; Williams, M. Feeding 9 billion by 2050-Putting fish back on the menu. Food Secur. 2015, 7 , 261-274.

169. High Level Panel of Experts (HLPE). Sustainable Fisheries and Aquaculture for Food Security and Nutrition. A Report by the High Level Panel of Experts on Food Security and Nutrition of the Committee on World Food Security; High Level Panel of Experts (HLPE): Rome, Italy, 2014.

170. Naylor, R.L.; Hardy, R.W.; Bureau, D.P.; Chiu, A.; Elliott, M.; Farrelle, A.P.; Forstere, I.; Gatlin, D.M.; Goldburg, R.J.; Hua, K.; et al. Feeding aquaculture in an era of finite resources. Proc. Natl. Acad. Sci. USA 2009, 106, 15103-15110.

171. FAO. The State of World Fisheries and Aquaculture 2014. Opportunities and Challenges; FAO: Rome, Italy, 2014.

172. De Graaf, G.; Garibaldi, L. The Value of African Fisheries. FAO Fisheries and Aquaculture Circular. No. 1093; FAO: Rome, Italy, 2014; p. 76.

173. Beveridge, M.C.M.; Thilsted, S.H.; Phillips, M.J.; Metian, M.; Troell, M.; Hall, S.J. Meeting the food and nutrition needs of the poor: The role of fish and the opportunities and challenges emerging from the rise of aquaculture. J. Fish Biol. 2013, 83, 1067-1084.

174. Bezabih, M.; di Falco, S. Rainfall variability and food crop portfolio choice: Evidence from Ethiopia. Food Secur. 2012, 4, 557-567.

175. Kandulu, J.M.; Bryan, B.A.; King, D.; Connor, J.D. Mitigating economic risk from climate variability in rain-fed agriculture through enterprise mix diversification. Ecol. Econ. 2012, 79, $105-112$.

176. Hazell, P.B.R.; Hess, U. Drought insurance for agricultural development and food security in dryland areas. Food Secur. 2010, 2, 395-405.

177. Haggblade, S.; Hazell, P.; Reardon, T. The rural non-farm economy: Prospects for growth and poverty reduction. World Dev. 2010, 38, 1429-1441.

178. Mellor, J.W. High rural population density Africa-What are the growth requirements and who participates? Food Policy 2014, 48, 66-75.

179. Berdegué, J.A.; Ricardo Fuentealba, R. Latin America: The state of smallholders in agriculture. In Proceedings of the IFAD Conference on New Directions for Smallholder Agriculture, Rome, Italy, 24-25 January 2011; p. 38.

180. Babatunde, R.O.; Qaim, M. Impact of off-farm income on food security and nutrition in Nigeria. Food Policy 2010, 35, 303-311.

181. Kumanayake, N.S.; Estudillo, J.P.; Otsuka, K. Changing sources of household income, poverty, and sectoral inequality in Sri Lanka, 1990-2006. Dev. Econ. 2014, 52, 26-51.

182. Wossen, T.; Berger, T. Climate variability, food security and poverty: Agent-based assessment of policy options for farm households in Northern Ghana. Environ. Sci. Policy 2015, 47, 95-107.

183. Imai, K.S.; Gaiha, R.; Thapa, G. Does non-farm sector employment reduce rural poverty and vulnerability? Evidence from Vietnam and India. J. Asian Econ. 2015, 36, 47-61.

184. FAO. The State of Food and Agriculture 2010-11. Women in Agriculture: Closing the Gender Gap for Development; FAO: Rome, Italy, 2011.

185. Ibnouf, F.O. Challenges and possibilities for achieving household food security in the Western Sudan region: The role of female farmers. Food Secur. 2011, 3, 215-231. 
186. Mohapatra, S. The pillars of Africa's agriculture. Rice Today 2011, 10, 22-23.

187. Arora-Jonsson, S. Virtue and vulnerability: Discourses on women, gender and climate change. Glob. Environ. Chang. 2011, 21, 744-751.

188. Figueiredo, P.; Perkins, P.E. Women and water management in times of climate change: Participatory and inclusive processes. J. Clean. Prod. 2013, 60, 188-194.

189. Ndiritu, S.W.; Kassie, M.; Shiferaw, B. Are there systematic gender differences in the adoption of sustainable agricultural intensification practices? Evidence from Kenya. Food Policy 2014, 49, $117-127$.

190. Fischer, E.; Qaim, M. Gender, agricultural commercialization, and collective action in Kenya. Food Secur. 2012, 4, 441-453.

191. Rijkers, B.; Costa, R. Gender and rural non-farm entrepreneurship. World Dev. 2012, 40, 2411-2426.

192. Ruijs, A.; Zimmermann, A.; van den Berg, M. Demand and distributional effects of water pricing policies. Ecol. Econ. 2008, 66, 506-516.

193. Dono, G.; Giraldo, L.; Severini, S. Pricing of irrigation water under alternative charging methods: Possible shortcomings of a volumetric approach. Agric. Water Manag. 2010, 97, 1795-1805.

194. Cooper, B.; Crase, L.; Pawsey, N. Best practice pricing principles and the politics of water pricing. Agric. Water Manag. 2014, 145, 92-97.

(C) 2015 by the authors; licensee MDPI, Basel, Switzerland. This article is an open access article distributed under the terms and conditions of the Creative Commons Attribution license (http://creativecommons.org/licenses/by/4.0/). 